This is the author's Post-print version (final draft post-refereeing as accepted for publication by the journal). The definitive, peer-reviewed and edited version of this article is published as: van Ham M. and Manley D. (2009) Social Housing Allocation, Choice and Neighbourhood Ethnic Mix in England. Journal of Housing and the Built Environment 24, 407-422. http://dx.doi.org/10.1007/s10901-009-9158-9

\title{
Social Housing Allocation, Choice and Neighbourhood Ethnic Mix in England
}

\author{
Maarten van Ham* (Corresponding Author) and David Manley**
}

Centre of Housing Research, School of Geography and Geosciences, Irvine Building, University of St Andrews, North Street, St Andrews, Fife, KY16 9AL

*maarten.vanham@st-andrews.ac.uk, ***d.manley@st-andrews.ac.uk

\begin{abstract}
Driven by a concern about the negative side effects of ethnic concentration neighbourhoods, many European governments aim to create more ethnically and socioeconomically mixed neighbourhoods. At the same time, housing policy aims to give tenants more choice in how and where they live. The objectives of these two policies might conflict as offering people choice has the potential to increase self-segregation, especially across ethnic groups. This paper studies the effect of choice-based letting on (self) segregation in housing association stock in England. We analyse whether households who let their property under choice-based letting end up in neighbourhoods with different levels of ethnic concentrations than households who are matched to a dwelling using the traditional allocation system. We focus on how the effect of choice-based letting differs for ethnic minority households and nonethnic minority households. Using unique data on all lettings made in the housing association sector in England in 2006/2007 and an ordered logit regression model we show that ethnic minority households are more likely to let a property in an ethnic concentration neighbourhood than non-ethnic minority households. Ethnic minorities letting their property under choicebased letting are the most likely to accept a dwelling in an ethnic concentration neighbourhood.
\end{abstract}

Keywords: Social housing; Choice-based letting; Ethnicity; Neighbourhood; Ethnic Mix; Segregation; England

\section{Introduction}

Segregation along ethnic or socio-economic lines is considered to be problematic for a variety of reasons, not least because of the potential for segregation to cause and reinforce social exclusion (Pawson \& Kintrea, 2002). Segregation may prevent individuals from accessing better employment, housing or other social opportunities, hindering the improvement of personal circumstances (see Dekker \& Rowlands, 2005, p.111). At the macro level, segregation can hinder the development of a multicultural society by facilitating resentment and mistrust between different communities in society. A report into public disorder in cities and towns in Northern England during 2001 concluded that one of the major causes of the violence was "the 
fragmentation and polarisation of communities - on economic, geographical, racial and cultural lines - on a scale which amounts to segregation, albeit to an extent by choice" (Denham, 2001, p.8).

The British Government has expressed a particular concern with regard to the concentration of ethnic minorities in social housing in England (Independent Review Team, 2001; Commission for Racial Equality, 1990; 2004; Cabinet Office, 2003; Home Office 2001). Burrows (1999) found that ethnic minorities are overrepresented in social housing: of the nonethnic population $11 \%$ are housed in the social sector while the equivalent figure for ethnic minorities is $19 \%$. These averages hide substantial regional variations. In London, for instance, over $31 \%$ of all ethnic minorities lived in social housing. The social housing sector in England has been progressively reduced over the last 20 years, and currently comprises only $18 \%$ of the total housing stock (SEH, 2007). Most of the more desirable stock has been sold to sitting tenants under the right to buy and rates of new construction are at historically low levels (Pawson \& Watkins, 2007). The outcome of these processes has been the residualisation of the remaining stock which is frequently maligned as the "tenure of last resort" for those who are unable to afford home ownership (Taylor, 1998). The shrinking of the social sector has reduced the choice for households requiring social housing which is likely to affect the ethnic minority population more than the white population. Clapham and Kintrea (1984) already noted that socio-economic groups are not randomly distributed in social housing with the worst off and ethnic minorities frequently accessing the worst housing and neighbourhoods.

To reduce the negative effects of segregation on individuals and society the British Government set out to create more ethnically and socio-economically mixed neighbourhoods (see for instance DETR, 2000a; ODPM, 2005). The social sector can play a crucial role in this objective as it is one of the few sectors of the housing market where the government can directly influence outcomes. Creating mixed neighbourhoods requires government intervention through housing policy by either influencing neighbourhood tenure mix - mixing owners and renters - or by influencing the ethnic and socio-economic mix of tenants in social housing through the allocation system of social housing (Bolt et al., 2008; Van Daalen \& Van der Land, 2008). Purposely creating ethnically mixed neighbourhoods is controversial and may be associated with ideas of social engineering. Often governments use policies aimed at creating a socio-economic mix in an attempt to indirectly create ethnically mixed neighbourhoods (see Bolt et al., 2008).

The Housing Green Paper, Quality and Choice: A decent home for all (DETR, 2000b) placed choice at the centre of British housing policy. The introduction of choice-based letting in 2001 was designed to empower people in social housing to make decisions over how and where they live (DETR, 2000b, Brown \& Yates, 2005; Brown \& King, 2005). Choice-based letting allows applicants to bid on properties of their 'choice' instead of being allocated to a dwelling by a housing officer (Kullberg, 1997; 2002). The objectives of policies to create socially mixed neighbourhoods and policies to give people more choice on the housing market are potentially contradictory. Concerns have been expressed that offering people choice in residential locations through choice-based letting has the potential to increase self-segregation along ethnic lines (ODPM, 2004; CLG, 2006; Pawson \& Watkins, 2007). It is well established that there are differences between ethnic groups in the desired ethnic mix of the neighbourhoods in which they live. Over time, these (sometimes small) differences can lead to marked patterns of ethnic segregation (Schelling, 1969, 1971; see Clark, 1991 for the US; Van Ham \& Feijten, 2008 for the Netherlands). 
Currently, very little is known about consumer responses to choice-based lettings (see Kullberg, 2002 for the Netherlands) and choice-based letting outcomes in terms of their spatial or distributional effects (Pawson \& Watkins, 2007). A report commissioned by the Department of Communities and Local Government (CLG, 2006) Monitoring the Longer Term Impact of Choice Based Lettings concluded that there is no evidence that choice-based letting had resulted in greater ethnic segregation. It was also reported that choice-based letting appears to produce a more spatially dispersed rather than concentrated pattern of lettings to ethnic minority households. In a paper based on the same 13 case studies, Pawson and Watkins (2007) state that the above conclusions possibly do not reflect experiences of all British social landlords using choice-based letting (Pawson \& Watkins, 2007). The study reported in this paper aims to give a more complete picture of the effect of choice-based letting on (self) segregation in housing association stock in England. We analyse whether households who let their property under choice-based letting end up in neighbourhoods with different levels of ethnic concentrations than households who are matched to a dwelling using non-choice-based letting systems. Special attention is paid to how the effect of choice-based letting differs for ethnic minority households and non-ethnic minority households. We use unique data on all lettings made in the housing association sector in England in 2006/2007 collected for the Housing Corporation and model the effect of ethnicity and choice-based letting on the type of destination neighbourhood using an ordered logit model.

\section{Background and literature review}

There is a heated debate on whether the rise in the percentage of ethnic minorities in Great Britain (increasing from 6\% of the total population in 1991 to almost $9 \%$ in 2001, Sabater, 2008) has led to an increase in residential segregation along ethnic lines (see Robinson, 2007 for a review of ethnic segregation literature). Champion (1996), using the 1991 Census, showed that in England ethnic minorities are spatially dispersed and that areas with the highest concentrations of ethnic minorities do not match the image of racialised ghettos as found in the USA (see also Peach, 1996; Johnston et al., 2002). Using the 2001 Census, Johnston (2006, p. 988) confirmed the pattern of ethnic dispersion observed in 1991 but also noted that there are "distinct ethnic Enclaves ... not only of London and other large cities (especially Birmingham), but also of a number of other urban centres". In an analysis combining both the 1991 and the 2001 Census, Dorling and Rees (2003; 2004) and Dorling and Thomas (2004), demonstrated that "while many aspects of society in the UK became more polarised geographically over the course of the 1990s, this was generally not the case for people's ethnicity" (Dorling \& Thomas, 2004, p.36). In an in-depth demographic analysis of Bradford one of the cities of Northern England that experienced race riots in 2001 - Simpson (2004) concurred with the overall pattern of stable levels of segregation as identified in the 1991 and 2001 Census analyses. However, Simpson did highlight some significant changes in local levels of segregation and identified that the driver behind these changes was natural population growth in the South Asian community.

A report commissioned to investigate the causes of the 2001 "Race Riots" described a much more ethnically segregated society than the census analyses and the demographic analysis of Bradford had identified, and suggested that ethnic concentration as a result of residential self-segregation was central to the tension and unrest (Robinson, 2007). The 
Independent Review Team (2001, p. 9) highlighted that the "separate educational arrangements, community and voluntary bodies, employment, places of worship, language, social and cultural networks means that many communities operate on the basis of a series of parallel lives". The report criticised the role played by Housing Policy and housing provision in creating segregated communities noting that, in many cases, the segregation was self enforced with ethnic minorities choosing to live in communities comprised predominantly of people of the same ethnicity. To avoid a repeat of the 2001 riots, the reports promoted the creation of ethnically mixed communities (DETR, 2000a; ODPM, 2005).

Around the same time of the race riots report, the British Government started to promote housing choice for those in the social housing sector (DETR, 2000b). Prior to 2001 social housing in England was exclusively allocated using waiting lists, and households were matched to suitable properties by social housing providers. Housing needs and the priority levels of applicants were assessed using points or category based systems (Pawson \& Watkins, 2007). Housing officers used the outcome of the assessment to match households with available properties (in certain neighbourhoods). Whilst it was possible to turn down properties, refusal usually led to penalties such as temporary suspension from the housing waiting list (Pawson \& Watkins, 2007) or exclusion through one-offer-only policies (Pawson $\&$ Kintrea, 2002). As a result, those most in need - often ethnic minorities - ended up concentrated in the least desirable dwellings and neighbourhoods (Clapham \& Kintrea, 1984). The housing allocation system has been linked to current patterns of ethnic segregation as allocation practices from as far back as the 1950s intentionally and unintentionally promoted segregated outcomes (Peach, 1996; Somerville 2001). Discriminatory practices based on class and race were found to be part of the day-to-day working practice of housing officers (Malpass \& Murie, 1994). Henderson and Karn (1984; 1987) found in their study of social housing access in Birmingham that housing officers used criteria such as whether applicants 'deserve' a house and neighbourhood, whether neighbours were likely to complain and whether applicants would lower the standard of the neighbourhood in order to match applicants to vacant dwellings. Generally, the system of allocation by scoring was seen as being property-led rather than applicant-led (Pawson \& Kintrea, 2002, p.649). The allocation process was overly bureaucratic, lacked transparency and did not reflect the needs and preferences of the tenant as priorities (Clapham \& Kintrea, 1991).

The 2000 Housing Green Paper (DETR, 2000b) introduced the concept of choice in the social housing sector as part of a wider drive of welfare reforms aimed at empowering the users of public services (Pawson \& Watkins, 2007). A choice-based letting system was proposed which was modelled on the 'advert model' or 'supply model' developed in the late 1980s in the city of Delft in the Netherlands (Kullberg, 1997, 2002). The system was designed to "open up the letting of social housing... [and] contrasted with traditional housing allocation systems where applicants are normally faced with only the stark choice of whether to accept or reject a property deemed "suitable"' (CLG, 2006, p.5). In the proposed choice-based letting system available housing is advertised, rather than allocated, and eligible households can 'bid' for properties. A variety of choice-based letting systems is operational using different forms of 'currency' - such as points, waiting time or housing need bands - to rank bidders (ODPM, 2004). Systems based on waiting time normally use some form of time-limited 'priority cards' for urgent (re)housing cases. It was thought that introducing choice-based letting would enable households in the social housing sector to access properties and locations that were more appropriate to their needs and in communities that they wished to live in. The Green Paper also 
set out that more choice should facilitate increased mobility as well as making better use of the social housing stock. The introduction of choice would enable those in social housing to better take 'ownership' of the housing and residential neighbourhood choices and outcomes that they experienced.

The introduction of choice-based letting while simultaneously seeking to create socially and ethnically mixed neighbourhoods creates a potential contradiction between policies. While the social housing sector needed to move away from meeting administrators' perceived needs of people to meeting the aspirations of applicants (Hill, 2005), the government is increasingly concerned with the need to engineer more socially and ethnically cohesive communities (Robinson, 2007). A possible side-effect of offering tenants more choice in residential locations is increased self-segregation along socio-economic and ethnic lines. In two pioneering papers, Schelling $(1969,1971)$ suggested that a person's choice of neighbourhood depends not only on the characteristics of the neighbourhood population, but also on the interaction between these and a person's own characteristics. Schelling used this idea to explain segregation in the USA theoretically and postulated that even small differences between blacks and whites in preferences towards the race of their neighbours and consequent moving behaviour can cumulate in aggregate to highly segregated neighbourhoods (see also Clark, 1991; Van Ham \& Feijten, 2008). Clark's empirical examination of the Schelling hypothesis for the USA (1991) confirmed that the thesis is broadly correct, but that the differences in neighbourhood preferences between blacks and whites in the USA are significantly greater than those postulated by Schelling (see also other studies such as Clark, 1992; 2002; Ihlanfeldt \& Scafidi, 2002; Ioannides \& Zabel, 2003). Using data from the Netherlands, Van Ham and Feijten (2008) and Van Ham and Clark (forthcoming) found that the native Dutch population is more likely to express a wish to leave ethnic concentration neighbourhoods, and to subsequently actually leave these neighbourhoods, than ethnic minorities themselves. In the Scottish context, Bowes and colleagues (1997) used interviews and concluded that members of the Pakistani community in Glasgow found the neighbourhood they lived in more important than their dwelling needs: they accepted poor quality housing because of the importance of living with co-ethnics in the same neighbourhood.

A government report (CLG, 2006), evaluating the spatial distributional effects of choice-based letting, concluded that there has not been an increase in ethnic segregation since the introduction of choice in the social sector as could be expected based on the work by Schelling (1969, 1971). The evaluation report shows a drop in the proportion of ethnic minorities moving into ethnic concentration neighbourhoods (defined as a neighbourhood with over twice the local ethnic minority average) which is interpreted as evidence of increased choice resulting in more ethnically mixed neighbourhoods (CLG, 2006). Based on a small number of case studies, the report concludes that "there is no evidence that [choice-based letting] has resulted in more ethnically polarized patterns of letting than those arising from previous lettings systems where decisions on which properties to offer to which applications were largely in the hands of landlord staff" (CLG, 2006, p.14; see also Pawson \& Watkins, 2007). The CLG report also recorded that there had been an increase in the number of moves made by ethnic minority households, noting that "by and large, social landlords who have introduced choice-based lettings have seen a rising proportion of their properties being let to minority ethnic households" (CLG, 2006, p.13).

Although there seems to be agreement that levels of ethnic segregation in England have not increased in recent years, we cannot conclude that mechanisms of self-segregation are not 
at work as even constant levels of segregation might point at mechanisms of self-segregation. Neighbourhoods are dynamic with households moving in and out over time. If levels of segregation have remained relatively constant and ethnic minority households have become more mobile this indicates that there are still processes at work 'feeding' ethnic minorities into ethnic concentration neighbourhoods. The introduction of choice-based letting could help to sustain current levels of segregation if ethnic minority groups choose to live in ethnic concentration neighbourhoods. In this paper we empirically investigate the effect of choicebased letting on social housing allocation in England. Following the Schelling (1969, 1971) inspired literature we hypothesise that the choice-based letting system increases the probability that ethnic minorities select themselves into ethnic concentration neighbourhoods.

It has been argued that the lack of real choice under choice-based letting, not selfsegregation by choice, might be a cause of sustained social and ethnic segregation in social housing. Brown and King (2005) state that choice in the context of choice-based lettings is a gift from the bureaucracy which controls it. Under choice-based letting, landlords set the rules of the game as applicants may only bid on property deemed suitable for their needs. Because applicants are deprived of control, choice-based letting ultimately fails to empower consumers of social housing (Brown \& King, 2005). Having choice means being able to select a preferred option from distinctive alternatives. In social housing - a safety net for those without options distinctive alternatives might not be available to the same extent as in, for example, health care or education. An essential prerequisite for rational choice satisfying housing desires is information (knowledge) about alternatives (see Elster, 1999 as in Brown \& King, 2005). Some social housing applicants in choice-based letting will have more information than others and this will bias the allocation system in their favour (Brown \& King, 2005). Research in the Netherlands by Kullberg (2002) showed that applicants with low incomes and those from ethnic minority groups (often overlapping groups) were more likely to lack understanding of the choice-based letting system and therefore fared less well in terms of housing outcomes. Also those with urgent or specific housing needs are likely to be disadvantaged in a choicebased letting system as they will bid on the easiest-to-get dwelling which matches their needs which increases the likelihood to be accommodated in a less desirable area. As a result of the above, concerns have been expressed that the choice-based letting model might be detrimental to the interests of already disadvantaged groups (Pawson \& Watkins, 2007). Ethnic minorities may end up in ethnic concentration neighbourhoods not as a result of choice, but as a result of a lack of choice - either because of a lack of knowledge or because of urgent housing needs. It has also been argued that ethnic minorities 'choose' ethnic concentration neighbourhoods because they want to avoid other areas known or perceived to suffer from racial tension (CLG, 2006).

\section{Data and Methods}

The data used in this study were assembled from COntinuous REcording (CORE, 2007) which records information on the characteristics of both the household and the dwelling each time a letting of housing association property is made in England. All housing associations with more than 250 units or 250 bed spaces in England are required by the Housing Corporation to complete CORE logs fully and accurately. Social landlords that are smaller than 250 units or bed spaces, or not registered with the Housing Corporation but affiliated to the National 
Housing Federation are invited to complete CORE logs. CORE was launched in 1989 and around 600 housing associations are now recording more than 125,000 general needs lettings, 90,000 supported housing lettings and 16,000 sales per year. The Centre for Housing Research (CHR) at the University of St Andrews has managed CORE since 1999. The CORE data is unique because it gives an up to date and detailed overview of almost all housing association lettings in England (so it is not a sample). In this paper we used information on 122,259 2006/2007 lettings for which we have information on both the origin and destination Output Areas of tenants. Output Areas, containing on average 296 people, are the lowest spatial units for which aggregate level statistics are available in England. We linked the percentage of ethnic minorities in origin and destination Output Area to each letting record in our data. In this study we used Output Areas as a proxy for a household's local neighbourhood.

The dependent variable derived from the 2001 British Census $^{1}$ (Office for National Statistics, 2001) measures the percentage of ethnic minorities in the destination output area in six categories: 0 to $2.5 \% ; 2.5$ to $5 \% ; 5$ to $10 \% ; 10$ to $20 \% ; 20$ to $40 \%$ and 40 to $100 \%$ (see descriptives in Table 1). Because the dependent variable is ordinal - a variable with more than two categories that can be ranked in a certain order, but without fixed intervals - we used ordered logit regression. This model is also known as the proportional odds model because the odds ratio of the event is independent of the relevant category. In ordered logit, a linear function is estimated of the independent variables and a set of cut points, which represent an underlying score (see Feijten \& Mulder, 2005 for a housing related example). The coefficients of the independent variables can be interpreted as coefficients estimated in an ordinary logit model. Filling in the full regression equation produces a raw outcome value for each letting in the data. To evaluate the probability that a household moves into a property in one of the six categories of Output Areas (based on the percentage of ethnic minorities in the Output Area) one needs to calculate a probability for all six categories using the model outcome and the five cut points (identified as $\mathrm{K}_{1}$ to $\mathrm{K}_{5}$ ) produced by the model. For example, the probability to move into an Output Area with 0 to $2.5 \%$ ethnic minorities is:

$$
P=\frac{1}{1+\exp \left(\text { outcome }-K_{1}\right)}
$$

The probability of moving into an Output Area with 2.5 to $5 \% ; 5$ to $10 \%$; 10 to $20 \%$; and 20 to $40 \%$ ethnic minorities is calculated using the following equation where $K_{n}$ represents the cut point associated with the category in question:

$$
P=\frac{1}{1+\exp \left(\text { outcome }-K_{n}\right)}-\frac{1}{1+\exp \left(\text { outcome }-K_{n-1}\right)}
$$

The probability to move into Output Areas with $40-100 \%$ ethnic minorities is:

$$
P=1-\frac{1}{1+\exp \left(\text { outcome }-K_{5}\right)}
$$

When combined the probabilities for all six categories will add up to 1, while the most likely destination neighbourhood will be identified as the one with the highest probability (see

\footnotetext{
${ }^{1}$ Census output is Crown copyright and is reproduced with the permission of the Controller of HMSO and the Queen's Printer for Scotland.
} 
Menard, 2002). Because the models included both individual level characteristics and area level characteristics and the data included multiple individuals per Output Area, the standard errors have been adjusted for clustering of individuals on the area level to account for the nonrandom distribution of individuals in neighbourhoods.

--- Table 1 please around here ---

Table 1 gives summary statistics of all independent variables used in the multivariate models. Note that we only use 121,065 lettings in our model due to a limited number of missing values on some of the variables used. Most variables were coded as dummies. Ethnic minority households were defined as households where the head does not belong to any of the following categories: White, White Irish or White Other. The White category includes heads of households born within the United Kingdom and the White Irish category includes heads of households born in the Irish Republic. The White Other category includes any other white heads of household. It is therefore diverse in composition including migrants from Europe, America, and Australasia. Ethnic minorities were coded as 1 and others were coded as 0 . Employment status was measured in three categories: employed (reference category), unemployed, and other. Household composition was measured in four categories: single, single parent, two adult household with children, two adults without children (reference category), and other. Dummy variables were created for lettings made in Supported Housing, lettings made to households new to the housing association sector, lettings made in new stock (new compared to existing stock), and choice-based lettings. Age of the head of household was measured in years. The number of bedrooms in the property was not available for all Supported Housing properties. For the lettings where this information was missing, the average number of bedrooms was imputed which gives unbiased estimates (see Cohen \& Cohen, 1975, chapter 7).

Because the destination neighbourhood can not be seen in isolation from the neighbourhood of origin, we also included the percentage of ethnic minorities in the origin neighbourhood (in the same six categories as the dependent variable) as independent variable in the model (see Bolt \& Van Kempen, 2002). The destination neighbourhood is characterised by the level of urbanism and whether (1) or not (0) the Output Area is located within the London Government Office Region (to account for the unique population and housing structures found in the capital city). The level of urbanism is measured using an ONS classification scheme which defines each output area into four settlement types: Urban, Small Town, Village, Dispersed Rural (Bibby \& Shepherd, 2004).

\section{Results}

Before we discuss the results of the ordered logit regression we describe our data using origindestination matrices for the non-ethnic and ethnic populations (Tables $2 \mathrm{a}$ and $2 \mathrm{~b}$ ). The matrices show the percentage of households moving from each of the six types of neighbourhoods (by percentage of ethnic minorities) to each other type. Remember that we are using flow data as all households in the data (lettings in housing association stock) have moved. The general picture from both matrices is that most households move into neighbourhoods with the same percentage of ethnic minorities as the neighbourhood from which they came (see the percentages on the diagonal). This is as expected from the mobility literature (see for instance 
Clark \& Dieleman, 1996; Bolt et al., 2008). There are however some interesting differences in the mobility patterns between the two groups. The non-ethnic minority population (Table 2a) tend to either stay in neighbourhoods with a low percentage of ethnic minorities or leave neighbourhoods with high percentages of ethnic minorities. The ethnic minority population (Table $2 b$ ) tend to either stay in neighbourhoods with a high percentage of ethnic minorities or move to neighbourhoods with a high percentage of ethnic minorities. For example, of all nonethnic minorities previously in neighbourhoods with $20-40 \%$ ethnic minorities $57.3 \%$ move to neighbourhoods with lower concentrations of ethnic minorities, $30.7 \%$ move to similar neighbourhoods and $12.0 \%$ move to neighbourhoods with a higher percentage of ethnic minorities. Of all ethnic minorities previously in neighbourhoods with $20-40 \%$ ethnic minorities $29.8 \%$ move to neighbourhoods with lower concentrations of ethnic minorities, $44.2 \%$ move to similar neighbourhoods and $26.0 \%$ move to neighbourhoods with a higher percentage of ethnic minorities. The origin and destination matrices suggest that the neighbourhood outcomes for ethnic and non-ethnic groups are very different. However, composition effects of the population might be responsible for these differences and therefore we need to control for socio-demographic and housing characteristics.

--- Table 2a please around here ---

--- Table $2 \mathrm{~b}$ please around here ---

Table 3 shows the results of an ordered logit regression, modelling destination neighbourhood ethnic minority concentration in six categories. The log likelihood of the model reported shows significant improvement compared to an intercept only model. The main variables of interest are a dummy indicating whether or not the household is categorised as belonging to an ethnic minority group and a dummy indicating whether or not the letting was made using the choicebased letting system. The results show that, after controlling for all other variables in the model, ethnic minorities are significantly more likely than others to move to a neighbourhood with a high percentage of ethnic minorities. This result confirms the findings from Table $2 \mathrm{a}$ and $2 \mathrm{~b}$. The choice-based letting dummy is not significant, but the interaction effect between the choice-based letting dummy and the ethnic minority dummy is positive and significant. This indicates that ethnic minorities under choice-based letting are the most likely to move to neighbourhoods with a high percentage of ethnic minorities.

--- Table 3 please around here ---

The effects of the control variables in the model are as expected. With increasing age (for the head of household) households are less likely to move into neighbourhoods with a high percentage of ethnic minorities. The unemployed are more likely to enter neighbourhoods with higher percentages of ethnic minorities than the employed. Compared to households with two adults and no children, singles are more likely to move into neighbourhoods with higher percentages of ethnic minorities. Households new to the housing association sector are less likely to enter neighbourhoods with a high percentage of ethnic minorities than those moving within the sector. Households moving into a property let for the first time (a newly built property) are more likely to move into neighbourhoods with a high percentage of ethnic minorities than those moving into existing property. Households moving into supported 
housing are also more likely to move into neighbourhoods with a higher percentage of ethnic minorities. Supported housing is provided to those people who, for various reasons, are regarded as the most vulnerable in society. The higher the number of bedrooms in the rented property, the less likely it is that households move into a neighbourhood with a high percentage of ethnic minorities.

To control for local and regional differences in the structure of the housing market and for the fact that there are regional differences in ethnic minority concentrations and therefore in the probability to move into a neighbourhood with a high level of ethnic minorities we have included an additional set of dummies. The first set describes the level of urbanism of the spatial context of the destination Output Area. The results show that, as expected, moving into housing association property located in a city gives the highest probability to move into a neighbourhood with a high percentage of ethnic minorities. An additional dummy indicates whether households move into property located in London. The result show a positive London effect, reflecting the fact that London has the largest proportion of ethnic minorities in England. Finally, we included five dummies indicating the percentage of ethnic minorities in the Output Area of origin. These dummies control for what type of neighbourhood people were used to and control for characteristics of the local housing market. The results show that the higher the percentage of ethnic minorities in the origin neighbourhood, the higher the percentage of ethnic minorities in the destination neighbourhood. This result is in line with what we found in Tables $2 \mathrm{a}$ and $2 \mathrm{~b}$.

Finally, to assess the size of the effects of belonging to an ethnic minority group, choice-based letting and the interaction effect between ethnicity and choice-based letting, we completed the regression equation for four theoretical households moving from a neighbourhood with 10-20\% ethnic minorities: an ethnic minority household letting under choice-based letting; an ethnic minority household which is allocated a dwelling; a non-ethnic minority household which is allocated a dwelling; and a non-ethnic minority household letting under choice-based letting (Figure 1). All dummies except ethnicity and choice-based letting were set to the reference group (so scoring zero in the equation). Ethnicity and choice-based letting were varied depending on the household type in question. Age and the number of beds were given average values as reported in Table 1. As described in the data and method section, by using the raw output of the regression equation and the five cut points produced by the model it is possible to calculate the probability that a households moved into each of the six categories of destination neighbourhoods. As can be seen ethnic minorities (the two left hand side bars for each neighbourhood category) are less likely than non-ethnic minorities to move into neighbourhoods with less than $10 \%$ ethnic minorities and more likely to move into neighbourhoods with more than $10 \%$ ethnic minorities. The effect of choice-based letting is clearly different for ethnic minorities and non-ethnic minorities. For non-ethnic minorities there is no notable effect. For ethnic minorities, choice-based letting means that they are less likely to move into neighbourhoods with less than $10 \%$ ethnic minorities and more likely to move into neighbourhoods with more than $10 \%$ ethnic minorities.

--- Figure 1 please around here --- 


\section{Conclusions}

This paper set out to investigate the effect of choice-based letting on (self) segregation in housing association stock in England. This study was motivated by the apparent contradiction in Government policies of creating socially and ethnically mixed neighbourhoods whilst giving people more choice in where and how they live. Following the Schelling $(1969,1971)$ inspired literature we hypothesised that choice-based letting increases the probability that ethnic minorities select themselves into ethnic concentration neighbourhoods. Additionally, we acknowledged several other mechanisms through which choice-based letting could lead to segregation. Previous work (CLG, 2006; Pawson \& Watkins, 2007), based on a limited number of case studies, suggested that the introduction of choice-based letting has led to a stabilisation or even a slight decline of segregation. We argued that with households moving into and out of neighbourhoods all the time, processes of (self) segregation must be in place for the overall levels of segregation to stay the same.

Based on an ordered logit regression model we showed that households belonging to an ethnic minority group are more likely to move into neighbourhoods with a high percentage of ethnic minorities than non-ethnic minority households. Ethnic minorities who rented their dwelling though the choice-based letting system were found to have the highest probability to move into ethnic concentration neighbourhoods. Although the effect of choice-based letting is relatively small, this effect can have relatively large consequences for aggregate segregation patterns. The fact that we found that choice-based letting reinforces the existing patterns of segregation contradicts the findings of the CLG (2006) report. It is debatable whether the effects found can be attributed to real choice based on a household's preferences as discussed in the literature review (see Brown \& King, 2005). Interestingly, we also found that even without choice-based letting, ethnic minorities are the most likely of all to move into ethnic concentration neighbourhoods. There are several possible explanations for this. First, the results might reflect local demographic and housing market structures which we have not been able to fully control for in our model. Second, tenants still have limited choice using traditional allocation systems, as they have the option to refuse an offer. Third, ethnic minorities are more likely than others to have urgent housing needs and lack knowledge about alternative housing options. If real choice is absent under choice-based letting this may lead to selection into ethnic concentration neighbourhoods without applicants having a preference for such neighbourhoods.

Our data represented virtually all lettings made in housing association properties in 2006/2007 in England. Because we use dynamic flow data we can not comment on changes in overall levels of segregation in neighbourhoods. In England, the 2011 Census will be the next opportunity to nationally evaluate changes in segregation levels. In order to fully understand dynamic processes leading to (changes in) segregation, a full set of dynamic flow data on the level of neighbourhoods is needed, including information on households moving into and out of neighbourhoods. Only by using such information it is possible to assess to what extent choice-based letting contributes to overall levels of segregation. In-depth qualitative analysis is needed to assess whether any effects of choice-based letting on overall levels of segregation can be attributed to real choice based on preferences.

Based on the results presented in this paper it can be concluded that choice in where to live through choice-based letting contributes to the segregation of ethnic minority groups. Combining aims to create mixed communities and at the same time give people more choice 
will most likely require continuous and active policy intervention. It has been argued that the traditional allocation system gave policy makers more opportunities for steering households with certain characteristics into certain neighbourhoods than the new choice-based letting system (Van Kempen \& Idamir, 2003). A paper by Van Daalen and Van der Land (2008) on the future of choice-based lettings in the Netherlands signals that there is a need to adapt the current choice-based allocation system to change disadvantaged neighbourhoods into sustainable communities. One potential solution is a form of community lettings which seeks to influence the socio-economic and demographic composition of neighbourhoods through lettings by actively discouraging or preventing lets to certain ethnic or socio-economic groups (Pawson \& Kintrea, 2002). Such letting models based on neighbourhood and applicant profiling has been extensively used to create more mixed neighbourhoods in the Netherlands and especially in the city of Rotterdam (Bolt et al., 2008) but have not been extensively adopted in England (see Griffiths et al., 1996). Although a potential solution, the community letting model brings up images of social engineering not everyone is comfortable with.

The whole discussion surrounding the creation of mixed neighbourhoods originates from the assumption that residential segregation is negative. Drever (2004) found for Germany that this is not necessarily the case. She identified that segregation was not a barrier to intercommunity integration between minority groups and the majority German population. It has also been identified that segregation can have major positive effects for ethnic minorities living in ethnic concentration neighbourhoods (Cheshire, 2008). Creating mixed neighbourhoods might therefore not be the Holy Grail in preventing the negative effects of spatial community fragmentation. The consequences of forcing socio-economic and ethnic groups to mix in neighbourhoods, against mechanisms of residents' preferences, could create community tension and destabilise communities and neighbourhoods.

\section{References}

Bibby, P. \& Shepherd, J. (2004). Developing a New Classification of Urban and Rural Areas for Policy Purposes - the Methodology. HMSO, London.

Bolt, G. \& van Kempen, R. (2002). Moving Up or Moving Down? Housing Careers of Turks and Moroccans in Utrecht, the Netherlands. Housing Studies, 17, 401-422.

Bolt, G., van Kempen, R., \& Van Ham, M. (2008). Minority Ethnic Groups in the Dutch Housing Market: Spatial Segregation, Relocation Dynamics and Housing Policy. Urban Studies, 45, 1359-1384.

Bowes, A. Dar, N. \& Sim, D. (1997). Tenure preference and housing strategy: An exploration of Pakistani experiences. Housing Studies, 12, 63-84.

Brown, T. \& King, P. (2005). The power to choose: effective choice and housing policy. European Journal of Housing Policy, 5, 59-75.

Brown, T. \& Yates, N. (2005) Allocations and lettings - Taking customer choice forward in England? European Journal of Housing Policy, 5, 343-357.

Burrows, R. (1999). Residential Mobility and Residualisation. Journal of Social Policy, 28, 2752.

Cabinet Office (2003). Ethnic minorities and the labour market: Interim Analytical Report. Cabinet Office, London. 
Champion, T. (1996). Internal migration and ethnicity in Britain, (In P. Ratcliffe (Ed.) Social Geography and Ethnicity in Britain: Geographical Spread, Spatial Concentration and Internal Migration (Ethnicity in the 1991 Census, Vol.3), (pp.135-173). London: HMSO.)

Cheshire, P. (2008). Policies for Mixed Communities: Faith based Displacement Activity? (Paper presented at ESRC workshop on Gentrification and Social Mix, Kings College, London.).

Clapham, D. and K. Kintrea (1984). Allocation Systems and Housing Choice. Urban Studies, 21, 261-269.

Clapham, D. and K. Kintrea (1991). Housing Allocation and the Role of the Public Rented Sector. (In D Donnison, \& D. Maclennan (Eds). The Housing Service of the Future, (pp.53-74) Longman, Harlow.

Clark, W. (1991). "Residential Preferences and Neighbourhood Racial Segregation: A Test of the Schelling Segregation Model. Demography, 28, 1-19.

Clark, W. (1992). Residential Preferences and Residential Choices in a Multiethnic Context. Demography 29(3), 451-466.

Clark, W. (2002). Ethnic Preferences and Ethnic Perceptions in Multi-Ethnic Settings. Urban Geography, 23, 237-256.

Clark, W. \& Dieleman, F. (1996). Households and Housing: Choice and Outcomes in the Housing Market, Rutgers University, Center for Urban Policy Research, New Brunswick, N.J.

CLG, (2006) Monitoring the Longer Term Impact of Choice Based Lettings. Department for Communities and Local Government, London.

Cohen, J. \& Cohen, P. (1975). Applied Multiple Regression/Correlation Analysis for the Behavioral Sciences, New York: John Wiley \& Sons.

Commission for Racial Equality (1990). Racial Discrimination in an Oldham Estate Agency. Report of Formal Investigation into Normal Lester and Co. CRE, London.

Commission for Racial Equality (2004). Race and Council Housing in Hackney: A general Investigation. CRE, London.

CORE (2007). What is CORE? Retrieved September 13, 2007, from www.core.ac.uk/introduction.html.

Dekker, K. and R. Rowlands (2005). Tackling social cohesion in ethnically diverse estates. (In Van Kempen, R. Dekker, K. Hall, S. \& Tosics, I. Restructuring Large Housing Estates in European Cities: An Introduction (pp.105-126.) Bristol, UK: Policy Press.)

Denham, J. (2001). Building Cohesive Communities: A Report of the Ministerial Group on Public Order and Community Cohesion. Community Cohesion Unit, Home Office, United Kingdom.

DETR (2000a). Our Towns and Cities - The Future: Delivering an Urban Renaissance. Urban White Paper, HMSO, London.

DETR, (2000b). Quality and Choice: A Decent Home for All: The Housing Green Paper. Department of the Environment, Transport and the Regions, London.

Dorling, D. \& Rees, P. (2003). A nation still dividing: the British census and social polarization 1971-2001. Environment and Planning A, 35, 1287-1313.

Dorling, D. \& Rees P. (2004). A nation dividing? Some interpretations of the question. Environment and Planning A, 36, 369-373.

Dorling, D \& Thomas, B (2004). People and Places: A 2001 Census Atlas of the UK. The Policy Press, Bristol. 
Drever, A. (2004). Separate Spaces, Separate Outcomes? Neighbourhood Impacts on Minorities in Germany. Urban Studies, 41, 1423-1439.

Elster, J. (1999). Strong Feelings: Emotion, Addiction, and Human Behavior. Bradford Books.

Feijten, P. \& Mulder, C.H. (2005). Life-course experience and housing quality. Housing Studies, 20, 571-588.

Griffiths, M. Parker, J. Smith, R. Stirling, T. \& Trott, T. (1996). Community Lettings: Local Allocation Policies in Practice. York, York Publishing Services.

Henderson, J. \& Karn, V. (1984). Race, class and the allocation of public housing in Britain. Urban Studies, 21, 115-128.

Henderson, J. \& Karn, V. (1987). Race, Class and State Housing. Gower, London.

Hill, K., (2005). Speech by the Minister of Housing to the ODPM/CIH Conference on Choice Based Lettings Schemes. 26 January, 2005.

Home Office (2001). Building Cohesive Communities: A Report of the Ministerial Group on Public Order and Community Cohesion. Home Office, London.

Ihlanfeldt, K.R. \& Scafidi, B. (2002). Black self-segregation as a cause of housing segregation: evidence from the multi-city study of urban inequality. Journal of Urban Economics, 51, 366-390.

Independent Review Team (2001). Community Cohesion. A report of the Independent Review Team. Chaired by Ted Cantle, Home Office, London.

Iaonnides, Y. M. \& Zabel, J. E. (2003). Neighbourhood effects and housing demand. Journal of Applied Econometrics, 18, 563-584.

Johnston, R. (2006). School and Residential Ethnic Segregation: An Analysis of Variations across England's Local Education Authorities. Regional Studies, 40, 973-990.

Johnston, R. Forrest, J. \& Poulsen, M. (2002). Are there Ethnic Enclaves/Ghettos in English Cities? Urban Studies, 39, 591-618.

Kullberg, J. (1997). From waiting lists to adverts: the allocation of social rented dwellings in the Netherlands. Housing Studies, 12, 393-403.

Kullberg, J. (2002). Consumer's responses to choice based letting mechanisms. Housing Studies, 17, 549-579.

Malpass, P. \& Murie, A. (1994). Housing Policy and Practice, $4^{\text {th }}$ edition. MacMillan Press, London and Hong Kong.

Menard, S. (2002). Applied Logistic Regression Analysis, Sage Publications Inc.

ODPM (2004) Piloting Choice Based Lettings. An evaluation. Office of the Deputy Prime Minister, London.

ODPM (2005). Planning for mixed communities. London, Office of the Deputy Prime Minister.

Office for National Statistics. (2001). Census: Standard Area Statistics (England and Wales). ESRC/JISC Census Programme, Census Dissemination Unit, Mimas (University of Manchester).

Pawson, H. \& Kintrea K. (2002). Part of the Problem or Part of the Solution? Social Housing Allocation Policies and Social Exclusion in Britain. Journal of Social Policy, 31, 643667.

Pawson, H. \& Watkins, D. (2007). Quasi-marketising access to social housing in Britain: Assessing the distributional impacts. Journal of Housing and the Built Environment, 22, 149-175. 
Peach, C. (1996). Does Britain have ghettos. Transactions of the Institute of British Geographers, 21, 216-235.

Robinson, D. (2007). Living Parallel Lives? Housing, Residential Segregation and Community Cohesion in England. (In H. Beider (Ed) Neighbourhood Renewal and Housing Matters. (pp.163-185). Oxford, Blackwell.)

Sabater, A. (2008) Ethnic segregation over time and cohorts in England and Wales, 1991-2001. CCSR Working Paper 2008-14.

Schelling, T.C. (1969). Models of segregation. The American Economic Review, 59, 488-93.

Schelling, T.C. (1971). Dynamic models of segregation. Journal of Mathematical Sociology, 1, 143-186.

SEH (2007). Housing in England 2005/06: A report principally from the 2005/06 Survey of English Housing. Department for Communities and Local Government, London.

Simpson, L. (2004). Statistics of Racial Segregation: Measures, Evidence and Policy. Urban Studies, 41, 661-681.

Somerville, P. (2001). Allocating housing or letting people choose? (In D Cowan \& A Marsh (Eds) Two Steps Forward: Housing Policy Into the New Millennium (pp.113-132) Bristol, Policy Press.)

Taylor, M. (1998). Combating the Social Exclusion of Housing Estates. Housing Studies, 13, 819-832.

Van Daalen, G. \& Van der Land, M. (2008). Next Steps in Choice-based Letting in the Dutch Social Housing Sector. European Journal of Housing Policy, 8, 317-328.

Van Ham, M., \& Clark, W. A.V. (forthcoming). Neighbourhood mobility in context: household moves and changing neighbourhoods in the Netherlands. Environment and Planning A.

Van Ham, M. \& Feijten, P. (2008). Who wants to leave the neighbourhood? The effect of being different from the neighbourhood population on wishes to move. Environment and Planning A, 40, 1151-1170.

Van Kempen, R., \& Idamir, M. (2003). Housing allocation and ethnic minority groups: The effects of different housing allocation models on Moroccan households in two Dutch cities. Journal of Housing and the Built Environment, 18, 257-268. 
Table 1: Variable summary statistics $(\mathrm{N}=122,259)$.

\begin{tabular}{|c|c|}
\hline Variables & $\%$ \\
\hline \multicolumn{2}{|l|}{$\begin{array}{l}\text { Dependent variable (percentage ethnic minorities in } \\
\text { destination neighbourhood) }\end{array}$} \\
\hline $1: 0$ to $2.5 \%$ & 45.81 \\
\hline $2: 2.5$ to $5 \%$ & 17.56 \\
\hline $3: 5$ to $10 \%$ & 12.87 \\
\hline 4: 10 to $20 \%$ & 8.73 \\
\hline 5: 20 to $40 \%$ & 8.24 \\
\hline 6: 40 to $100 \%$ & 6.79 \\
\hline \multicolumn{2}{|l|}{ Independent variables } \\
\hline Ethnic Minority (ref = not ethnic minority) & 14.68 \\
\hline \multicolumn{2}{|l|}{ Economic Activity } \\
\hline Employed & 28.95 \\
\hline Unemployed & 32.68 \\
\hline Other Economic Activity & 38.37 \\
\hline \multicolumn{2}{|l|}{ Household type } \\
\hline Single & 53.72 \\
\hline Single Parent & 18.29 \\
\hline Two Adults Household with Children & 11.49 \\
\hline Two Adults without Children (reference) & 11.02 \\
\hline Other Household & 5.48 \\
\hline Supported Housing (ref = not Supported Housing) & 25.54 \\
\hline Choice-based letting (ref = other allocation system) & 23.20 \\
\hline New Tenant (ref = existing tenant) & 56.31 \\
\hline New Let $($ ref $=$ relet $)$ & 10.25 \\
\hline \multicolumn{2}{|l|}{ Urbanism of destination neighbourhood } \\
\hline Urban & 87.13 \\
\hline Small Town & 8.38 \\
\hline Villages & 3.87 \\
\hline Dispersed & 0.62 \\
\hline Destination neighbourhood London (ref= outside London) & 10.22 \\
\hline \multicolumn{2}{|l|}{ Percentage ethnic minorities in origin Neighbourhood } \\
\hline 0 to 2.5 & 44.85 \\
\hline 2.5 to $5 \%$ & 17.31 \\
\hline 5 to $10 \%$ & 12.53 \\
\hline 10 to $20 \%$ & 8.77 \\
\hline 20 to $40 \%$ & 8.41 \\
\hline \multirow[t]{2}{*}{40 to $100 \%$} & 8.13 \\
\hline & Mean \\
\hline Age & 43.75 (range 15 to 106$)$ \\
\hline Beds & 1.89 (range 1 to 7$)$ \\
\hline
\end{tabular}

Source: CORE, 2006/2007 (own calculations) 
Table 2a: Crosstabulation of origin and destination neighbourhood percentage ethnic minorities for all non ethnic minority lettings.

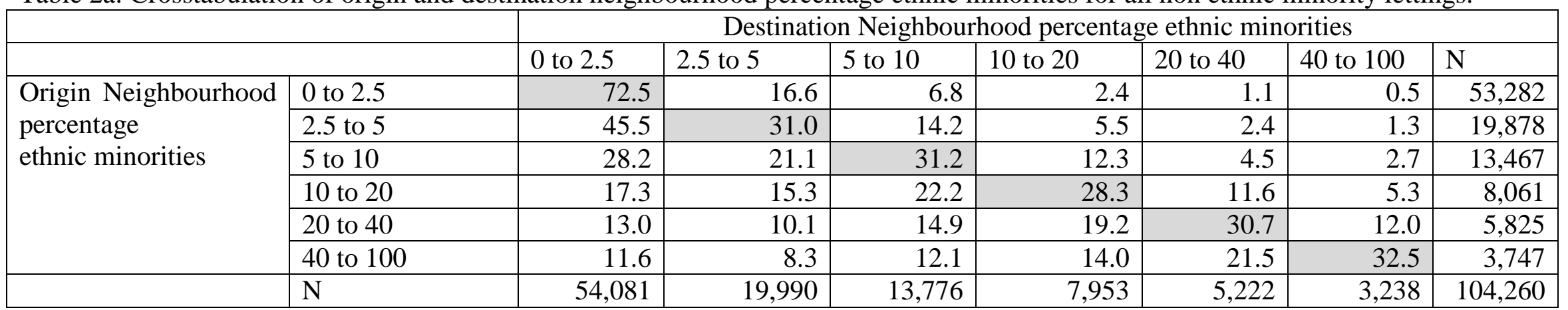

Source: CORE, 2006/2007 (own calculations)

Table 2b: Crosstabulation of origin and destination neighbourhood ethnicity for all ethnic minority lettings.

\begin{tabular}{|c|c|c|c|c|c|c|c|c|}
\hline & \multicolumn{7}{|c|}{ Destination Neighbourhood percentage ethnic minorities } \\
\hline & & 0 to 2.5 & 2.5 to 5 & 5 to 10 & 10 to 20 & 20 to 40 & 40 to 100 & $\mathrm{~N}$ \\
\hline \multirow{4}{*}{$\begin{array}{l}\text { Origin Neighbourhood } \\
\text { percentage } \\
\text { ethnic minorities }\end{array}$} & 2.5 to 5 & 29.6 & 26.1 & 19.1 & 10.9 & 8.6 & 5.7 & 1,307 \\
\hline & 10 to 20 & 5.8 & 8.3 & 15.5 & 29.3 & 26.1 & 15.0 & 2,648 \\
\hline & 20 to 40 & 2.7 & 3.3 & 7.7 & 16.2 & 44.2 & 26.0 & 4,358 \\
\hline & 40 to 100 & 1.5 & 2.8 & 4.6 & 10.8 & 28.3 & 52.1 & 6,079 \\
\hline
\end{tabular}

Source: CORE, 2006/2007 (own calculations) 
Table 3: Ordered logit regression of destination neighbourhood ethnic minority concentration in six categories (1: 0 to $2.5 \% ; 2: 2.5$ to $5 \% ; 3: 5$ to $10 \% ; 4: 10$ to $20 \% ; 5: 20$ to $40 \%$ and 6: 40 to $100 \%)$.

\begin{tabular}{|c|c|c|c|}
\hline & Coef. & S.e & Sig \\
\hline Ethnic Minority (ref = not ethnic minority) & 0.827 & 0.029 & $* * *$ \\
\hline Choice-based letting (ref $=$ all other allocation systems) & -0.015 & 0.032 & \\
\hline Interaction CBL*Ethnic & 0.146 & 0.060 & $* * *$ \\
\hline Age & -0.010 & 0.001 & $* * *$ \\
\hline Economic Activity (ref = employed $)$ & & & \\
\hline Unemployed & 0.053 & 0.019 & $* * *$ \\
\hline Other & -0.074 & 0.024 & $* * *$ \\
\hline Household type (ref = two adults) & & & \\
\hline Single & 0.144 & 0.025 & $* * *$ \\
\hline Single Parent & -0.002 & 0.039 & \\
\hline Two Adults + child(ren) & 0.009 & 0.037 & \\
\hline Other household & 0.177 & 0.039 & $* * *$ \\
\hline New Tenant $(r e f=$ existing tenant $)$ & -0.038 & 0.016 & $* *$ \\
\hline New Let $(r e f=r e l e t)$ & 0.223 & 0.055 & $* * *$ \\
\hline Supported Housing (ref $=$ not Supported Housing) & 0.239 & 0.055 & $* * *$ \\
\hline Number of Bedrooms & -0.097 & 0.020 & $* * *$ \\
\hline Urbanism of destination neighbourhood (ref Cities) & & & \\
\hline Small Town & -1.321 & 0.066 & $* * *$ \\
\hline Villages & -1.827 & 0.099 & $* * *$ \\
\hline Dispersed & -1.218 & 0.230 & $* * *$ \\
\hline Destination neighbourhood in London ( $r e f=$ outside London) & 1.157 & 0.056 & $* * *$ \\
\hline Percentage ethnic minorities in origin Neighbh $(r e f=0$ to 2.5$)$ & & & \\
\hline 2.5 to $5 \%$ & 0.958 & 0.021 & $* * *$ \\
\hline 5 to $10 \%$ & 1.743 & 0.027 & $* * *$ \\
\hline 10 to $20 \%$ & 2.444 & 0.034 & $* * *$ \\
\hline 20 to $40 \%$ & 3.035 & 0.047 & $* * *$ \\
\hline 40 to $100 \%$ & 3.838 & 0.050 & $* * *$ \\
\hline Cut point 1 & 0.244 & 0.062 & \\
\hline Cut point 2 & 1.394 & 0.064 & \\
\hline Cut point 3 & 2.510 & 0.069 & \\
\hline Cut point 4 & 3.555 & 0.076 & \\
\hline Cut point 5 & 4.923 & 0.089 & \\
\hline $\mathrm{N}$ & 121,065 & \multirow{3}{*}{\multicolumn{2}{|c|}{ (23) }} \\
\hline Wald (df) & 15,416 & & \\
\hline Log pseudolikelihood (initial value $=-192,287$ ) & $-164,423$ & & \\
\hline
\end{tabular}

$* *=\mathrm{p}<0.05, * * *=\mathrm{p}<0.001$

Source: CORE, 2006/2007 (own calculations) 
Figure 1: Estimated probabilities of moving to six types of neighbourhoods for four categories of household coming from neighbourhoods with $10-20 \%$ ethnic minorities.

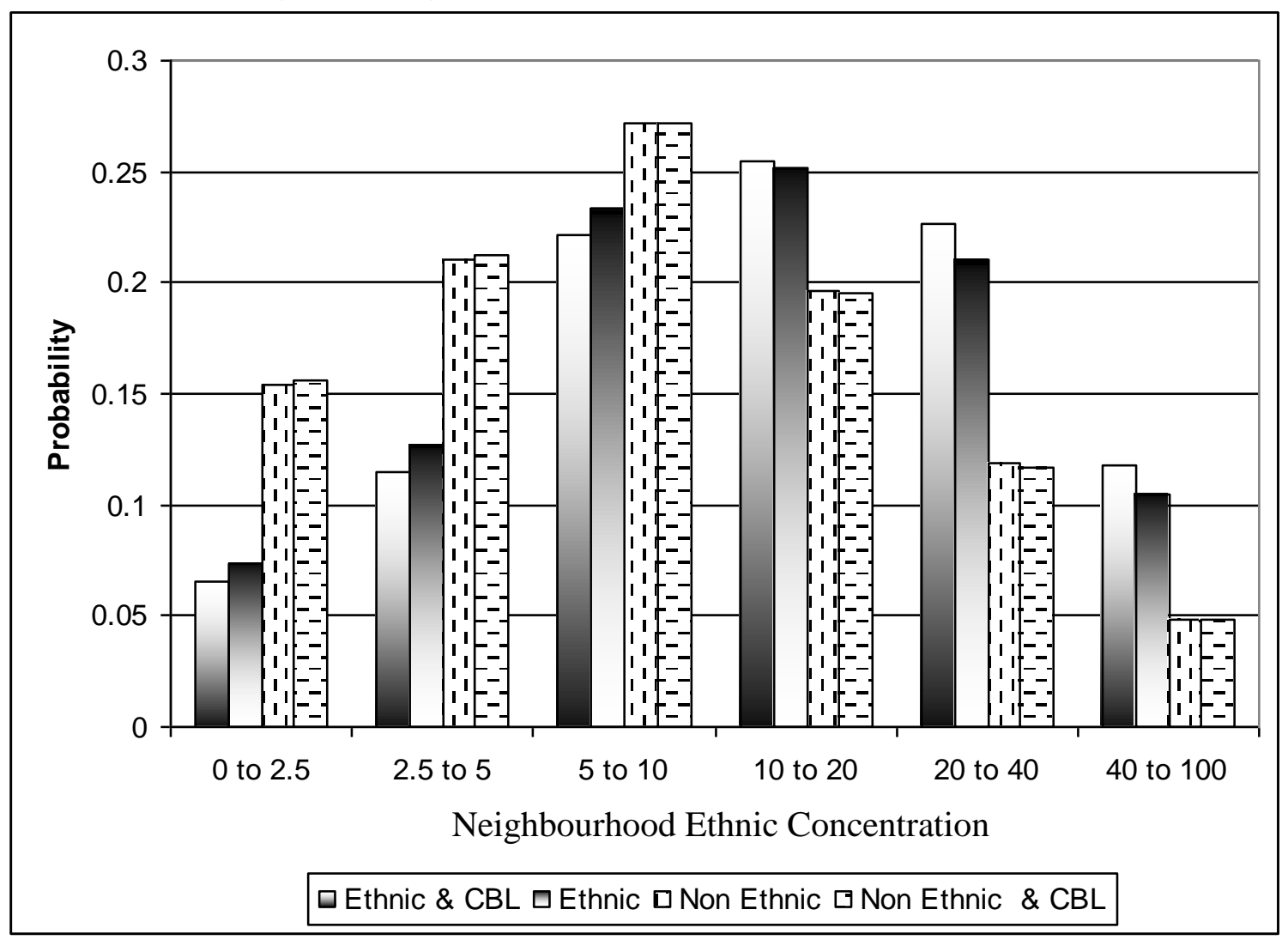

Source: CORE, 2006/2007 (own calculations) 